\title{
Pleomorphic T-cell leukaemia in a Caucasian adult: clinical phenotypic and functional characteristics
}

\author{
C.J. Hawkey ${ }^{1}$, A.C. Campbell ${ }^{2 *}$, G.A. Bird ${ }^{3}$, D.I. Gozzard ${ }^{1}$, R.A. Robins ${ }^{4}$ \\ and P.J. Toghill ${ }^{1}$
}

Departments of ${ }^{\prime}$ Medicine and ${ }^{2} I m m u n o l o g y$, University Hospital and ${ }^{4}$ Cancer Research Laboratories, Nottingham; ${ }^{3}$ Regional Immunology Laboratory, East Birmingham Hospital, Birmingham, UK.

\begin{abstract}
Summary: Pleomorphic T-cell leukaemia occurring in an adult Caucasian patient is described. The leukaemia cells expressed both antigenic determinants $\left(T_{4}\right.$ and $\left.T_{8}\right)$ normally detected separately on either helper or suppressor cells. They functioned as helper cells and there was evidence of unbridled antibody production. It is possible that a distinctive subtype of pleomorphic T-cell leukaemia occurs in Caucasian patients.
\end{abstract}

\section{Introduction}

At present, there is considerable interest in adult T-cell leukaemia (ATL; Uchiyama et al., 1977), a disease characterized by pleomorphic cells with convoluted nuclei and an association with a specific human retrovirus (HTLV) infection (Kalyanaraman et al., 1981, 1982; Popovic et al., 1982). The disease was first described in Japan, and British cases have been restricted to black West Indian patients (Catovsky et al., 1982). We reported a similar illness occurring in a Caucasian patient, characterized by typical pleomorphic cells which expressed an immature surface phenotype but functioned as helper cells.

\section{Case report}

A 58 year old swimming pool supervisor presented with a 2 week history of fever, malaise and shortness of breath, preceded by a fleeting diffuse macular rash. He had previously been well, had never been out of England, and had no known non-white ancestors.

Examination revealed generalized lymphadenopathy and hepatosplenomegaly. There were no skin lesions. His blood count showed $25 \times 10^{9} / 1$ leucocytes (66\% lymphocytes) and haemoglobin $11.1 \mathrm{~g} / \mathrm{dl}$. The lymphocytes were pleomorphic with some blast cells but a majority of mature forms with varying degrees of

Correspondence: C.J. Hawkey, D.M., M.R.C.P., Department of Therapeutics, University Hospital, Nottingham, NG7 2UH, UK.

* Present address: Department of Immunology, Leicester Royal Infirmary, Leicester, UK.

Accepted: 12 September 1984 nuclear convolution (Figure 1); some plasmacytoid cells were also present. Lymph node and bone marrow histology showed diffuse infiltration with these cells and a mild vascular proliferation. The serum immunoglobins were diffusely increased (maximum levels IgG $39.8 \mathrm{~g} / 1, \operatorname{IgA} 5.2 \mathrm{~g} / \mathrm{l}, \operatorname{IgM} 3.6 \mathrm{~g} / \mathrm{l}$ ). There were sustained high titres of antibodies to toxoplasma, cytomegalovirus, Epstein-Barr virus, autoantibodies to gastric parietal cells, smooth muscle and skeletal muscle, and a transient rheumatoid factor $(1 / 256)$. After transfusion, antibodies to red cells, white cells and platelets developed. These were associated with transfusion reactions and a steroid-responsive thrombocytopenia. After 8 months the patient developed an anterior and posterior uveitis. Antibody to HTLV was not detected in the serum. The patient did not, at any time, have a raised plasma calcium level.

Using monoclonal antibodies and staining for terminal deoxynucleotidyl transferase the leukaemic cells were shown to have an extraordinary phenotype (OKT $11^{+} 3^{+} 4^{+} 8^{+} 6^{-} \mathrm{TdT}^{-}$). Less than $5 \%$ of the circulating lymphocytes were of mature T-cell phenotype $\left(\mathrm{OKT} 3^{+} 4^{+} 8^{-}\right.$or OKT $\left.3+8^{+} 4^{-}\right)$, and less than $2 \%$ were B-cells (bearing surface immunoglobin). The leukaemic cells appear to correspond to a stage of differentiation between the common cortical thymocyte (OKT $11^{+} 4^{+} 8^{+} 6^{+} 3^{-}$) and the two mature ('helper' and 'suppressor') medullary thymocyte and peripheral T-cell subsets (Reinharz \& Schlossman, 1980). Functional analysis of the patient's lymphocytes showed that $2 \%$ spontaneously secreted IgG in vitro, suggesting polyclonal B-cell activation in vivo. Pokeweed mitogen stimulated coculture experiments revealed that the leukaemic cells 

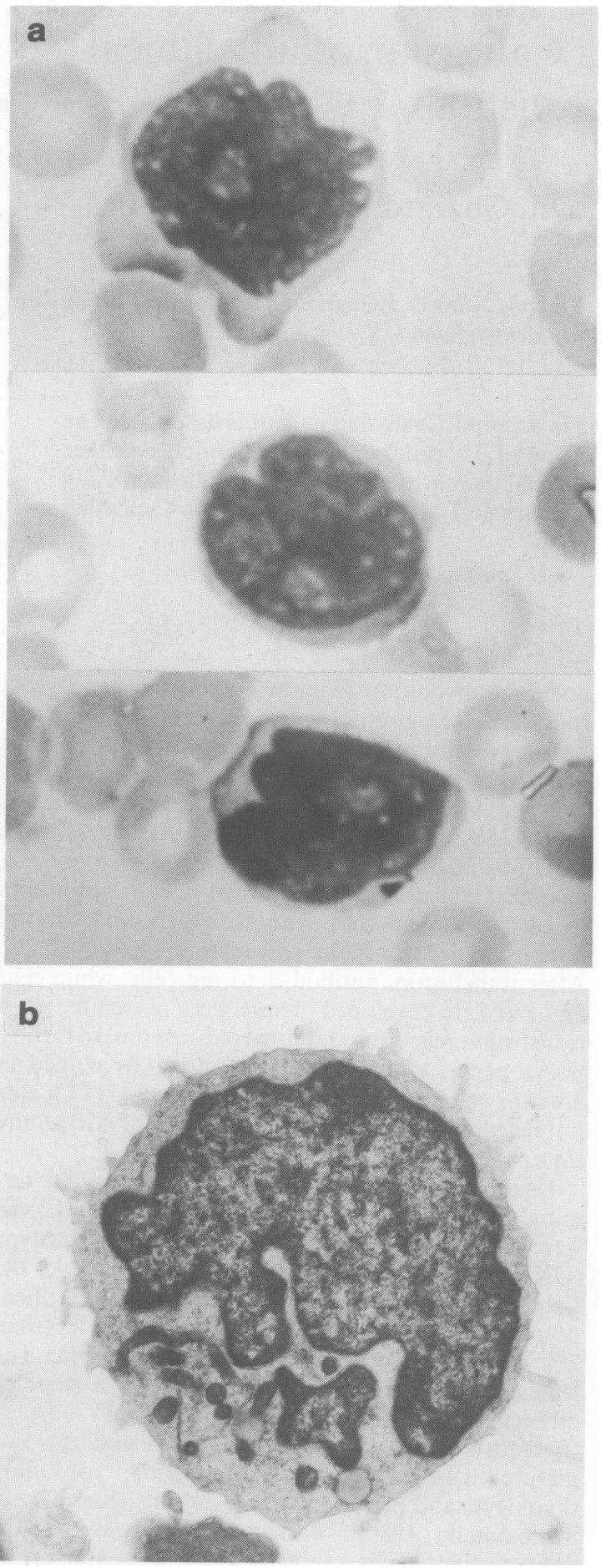

Figure 1 (a) Typical leukaemia cells by light microscopy, magnification $\times 6.700$ (peripheral blood). (b) Electron microscopy (bone marrow) $\times 16,000$. provided help for IgM and IgG synthesis by normal cells.

The patient received aggressive chemotherapy, bu击 it was not possible to eliminate the leukaemic cells an $\overline{8}$ an increasing proportion of blast cells was seen. He died 13 months after presentation; at post-mortem there was hepatosplenomegaly and infiltration off axillary and para-aortic lymph nodes but n₹ thymoma.

\section{Discussion}

The clinical and cytological features of this case were similar to those seen in Japanese and black patient $\overrightarrow{\mathbb{E U}^{\prime}}$ with ATL. The phenotype in ATL, however, is generally that of mature $\mathrm{T}$ helper/inducer cells $(\mathrm{OK}$ $3^{+} 4^{+} 8^{-}$; Boumsell et al., 1981; Haynes et al., 1981) although the cells paradoxically suppress immun oglobin synthesis in vitro (Hofman et al., 1982 Yamada, 1983). In this case, the phenotype was extremely unusual, in that individual leukaemic cells expressed both helper $\left(\mathrm{T}_{4}\right)$ and suppressor $\left(\mathrm{T}_{8}\right)$ antigens simultaneously. It may be that the patient's hypergammaglobulinaemia and high titres of a variety of antibodies, including autoantibodies, werw attributable to unbridled helper activity by the leukaemic cells.

There is one other published case of leukaemia witer this phenotype (Schnitzer et al., 1982). This was als pleomorphic T-cell leukaemia in a Caucasian adtîn with no HTLV antibodies. These two cases sugges $\overline{5}$ that a type of ATL may occur in Caucasian patients in the absence of HTLV infection. An analogy among $B$ cell neoplasms is the non-African Burkitt's lymphoma which, in contrast to the African form, is not associated with Epstein-Barr virus infection.

\section{Acknowledgements}

We are grateful to Dr A. Stevens (University Hospital, Nottingham) for advice with histology and electron micros-i copy, and to Dr P. Sarin (Laboratory of Tumour Cell Biology, Bethesda, Maryland) for screening for HTLV associated antibodies. 


\section{References}

BOUMSELL, L., BERNARD, A., REINHERZ, E.L., NADLER, L.M., RITZ, J., COPPIN, H., RICHARD, Y., DUBERTRET, L., VALENSI, F., DEGOS, L., LEMERLE, J., LANDRIN, G., DAUSSET, J. \& SCHLOSSMAN, S.F. (1981). Surface antigens on malignant Sezary and T-CLL cells correspond to those of mature T-cells. Blood, 57, 526.

CATOVSKY, D., GREAVES, M.F., ROSE, M., GALTON, D.A.G.. GOOLDEN, A.W.G., MCCLUSKY, D.R., WHITE, J.M., LAMPERT, I., BOURIKAS, G., IRELAND, R., BROWNELL, A.I., BRIDGES, J.M., BLATTNER, W.A. \& GALLO, R.C. (1982). Adult T-cell lymphoma-leukaemia in blacks from the West Indies. Lancet, i, 639.

HAYNES, B.F., METZGAR, R.S., MINNA, J.D. \& BUNN, P.A. (1981). Phenotypic characterisation of cutaneous T-cell lymphoma. New England Journal of Medicine, 304, 1319.

HOFMAN, F.M., SMITH, D. \& HOCKING, W. (1982). T-cell chronic lymphatic leukaemia with suppressor phenotype. Clinical and Experimental Immunology, 49, 401.

KALYANARAMAN, V.S., SARNGADHARAN, M.G., BUNN, P.A., MINNA, J.D. \& GALLO, R.C. (1981). Antibodies in human sera reactive against an internal structural protein of human T-cell lymphoma virus. Nature, 294, 271.

KALYANARAMAN, V.S., SARNGADHARAN, M.G., NAKAO, Y., ITO, Y., AOKI, T. \& GALLO, R.C. (1982). Natural antibodies to the structural core protein (P24) of the human T-cell leukaemia (lymphoma) retro-virus found in sera of leukaemic patient in Japan. Proceedings of the National Academy of Sciences of the United States of America, 79, 1653.

POPOVIC, M., REITZ, M.S., SARNGADHARAN, M.G., ROBERT-GUDOFF, M., KALYARANAM, V.S., NAKAO, Y., MIYOSHI, I., MINOWADA, J., YOSHIDA, M., ITO, Y. \& GALLO, R.C. (1982). The virus of Japanese adult T-cell leukaemia is a member of the human T-cell leukaemia virus group. Nature, 300, 63.

REINHERZ, E.L. \& SCHLOSSMAN, S.F. (1980). The differentiation and function of human T-lymphocytes. Cell, 19, 821.

SCHNITZER, B., LOVETT, E.J., HUDSON, J.L., MCLATCHEY, K.D., KEREN, D.F., DABICH, L. \& MITCHELL, B.F. (1982). Adult T-cell leukaemia-lymphoma with unusual phenotype. Lancet, ii, 1273.

UCHIYAMA, T., YODOI, J., SAGAWA, K., TAKATSUKI. K. \& UCHINO, H. (1977). Adult T-cell leukaemia: clinical and haematological features in 16 cases. Blood, 50, 481.

YAMADA, Y. (1983). Phenotypic and functional analysis of leukaemic cells from 16 patients with adult T-cell leukaemia/lymphoma. Blood, 61, 199. 